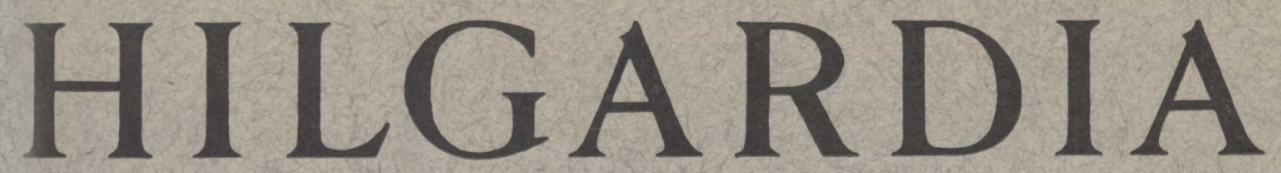

A Journal of Agricultural Science Published by the California Agricultural Experiment Station

CONTENTS

INFECTION OF PERENNIAL DELPHINIUMS BY CALIFORNIA-ASTER-YELLOWS VIRUS HENRY H. P. SEVERIN

\title{
CELERY CALICO ON PERENNIAL DELPHINIUMS AND CERTAIN OTHER HOST PLANTS
} HENRY H. P. SEVERIN

\section{PERENNIAL-DELPHINIUM RINGSPOT} HENRY H. P. SEVERIN and R. C. DICKSON

UNIVERSITY OF CALIFORNIA - BERKELEY, CALIFORNIA 


\section{CELERY CALICO ON PERENNIAL \\ DELPHINIUMS AND CERTAIN \\ OTHER HOST PLANTS}

HENRY H. P. SEVERIN 



\title{
CELERY CALICO ON PERENNIAL DELPHINIUMS AND CERTAIN OTHER HOST PLANTS ${ }^{1}$
}

\author{
HENRY H. P. SEVERIN ${ }^{2}$
}

\section{INTRODUCTION}

ONE OF THE viroses found in the course of the investigations of aster yellows on perennial delphiniums $(4)^{3}$ proved to be transmissible by juice inoculation and showed symptoms resembling those of calico on celery. Calico was reported by Severin and Freitag in 1935 (5). In a later paper (6) they described and figured the symptoms of the disease. But the disease has not hitherto been reported on delphiniums or any other species of the family Ranunculaceae.

An investigation was accordingly undertaken to determine whether one of the naturally occurring viroses of perennial delphiniums was caused by the celery-calico virus. Studies were made of the variable symptoms of the disease on this host plant, the incubation period of the disease, the recovery of the virus, and the vectors. A number of hybrids and horticultural varieties of perennial delphiniums were tested for susceptibility to celery calico. A few other host plants of the virus are reported in this paper.

Delphiniums in the field in California were found to be frequently infected with more than one virosis - as, for example, with aster yellows and the disease reported in this paper. This situation greatly complicates the problem, especially since the symptoms of these viroses are extremely variable, even when they occur singly. Little progress can be made unless multiple viruses can be separated, and attempts were therefore made to work out methods for doing this in delphinium and also in tomato. Much confusion in the literature dealing with delphinium viroses is caused by the failure of some plant pathologists to recognize and separate multiple viruses in naturally infected plants.

Heald and Burnett (2), working with delphiniums infected with what they called "stunt" (aster yellows) (4), reported that some of the symptoms were reproduced by juice inoculation to healthy transplants and seedlings grown in the greenhouse, but that the inoculated plants did not develop the proliferated inflorescence and virescence shown by the naturally infected plants. They state, "It seems probable that all of the

${ }^{1}$ Received for publication May 16, 1941.

- Associate Entomologist in the Experiment Station.

"Italic numbers in parentheses refer to "Literature Cited" at the end of this paper. 
observations are concerned with slightly different phases of a single disease although it is possible that more than a single virus disease is represented."

Burnett (1) states that healthy delphiniums inoculated with "macerated leaf tissue" from naturally infected delphiniums produced such symptoms as ringspot, necrosis, and chlorosis. Plants from which the virus was secured exhibited such symptoms as necrosis, chlorosis or yellowing, a witches'-broom effect, and a reversion of the floral parts to green, leafy structures. He assumed that a single virus produced extremely variable symptoms on delphinium and some other host plants, under different environmental conditions. In the present investigation, some of the host plants reported by Burnett for delphinium stunt were inoculated with celery-calico virus to test susceptibility and compare the symptoms with those described by Burnett.

\section{MATERIAL AND METHODS}

The sources of inoculum were delphinium, celery, cantaloupe, cucumber, Summer Crookneck squash, and tomato, all naturally infected with calico. The virus extract from these host plants was usually inoculated in the cotyledons of healthy cucumbers, and the virus was retained by repeated mechanical inoculation to cucumbers. Cucumbers were used because the symptoms developed rapidly on the cotyledons, often in 2 days. The carborundum method of inoculation described by Rawlins and Tompkins (3) was used.

The multiple viruses in naturally infected delphinium and tomato were separated by means of filter plants. The aster-yellows virus was separated from a virus complex in delphinium by means of previously noninfective leafhoppers.

\section{SYMPTOMATOLOGY}

The symptoms of celery calico on delphinium are very conspicuous in the field and can be noticed across three or four rows of plants. The basal or lower and intermediate leaves show pale-orange, amber, or lemonyellow, irregular areas, but the younger leaves never show symptoms of the disease.

A closer examination of the leaves showing symptoms from perennial delphiniums naturally and experimentally infected with calico reveals a considerable amount of variation in the patterns. A few of the oldest leaves of infected seedlings may show irregular, chlorotic areas on some or all of the lobes or divisions (plate $1, A, B$ ), or an entire leaf may assume a pale-orange or lemon color. Variations in the patterns may occur on the older leaves of the same plant, such as irregular discolora- 
tions on one leaf (plate $1, C$ ) and small green areas scattered in the chlorotic region of another leaf (plate $1, D$ ). Such green islands in the paleorange, amber, or lemon-yellow areas (plate $1, F$ ) are reliable symptoms of calico on celery and other host plants. Sometimes a lower leaf of an infected delphinium seedling may show chlorotic or green streaks (plate $1, E$; plate $2, D$ ).

Both naturally and experimentally infected delphiniums frequently show line or ring patterns. The lines are often broken, consisting of a series of chlorotic dots or dashes (plate $2, A, B$ ), or alternating green and yellow lines (plate $2, C$ ). Ring patterns resembling ringspots may be composed of chlorotic dots enclosing green areas (plate $2, E$ ); sometimes the chlorotic dots are arranged in groups. The rings may consist of concentric, alternating, yellow and green lines surrounding green centers (plate $2, F^{\prime}$ ).

The Chinese varieties of delphiniums (Delphinium grandiflorum) developed chlorotic, lateral shoots and the linear segments of the blades were yellow and failed to develop the variable symptoms previously described.

The virus of calico causes breaking in the color of pansies and violas (plate $6, K$ ), and this symptom is one method of identifying the virus; but the blossoms of naturally and experimentally infected delphinium were normal in appearance.

\section{EXPERIMENTAL INFECTION}

Since a considerable amount of variation occurs in the patterns on the leaves of delphinium plants naturally and experimentally infected with calico, inoculations of delphiniums were made with the virus extract from a number of naturally infected host plants obtained in various localities in California. Delphiniums showing symptoms of calico were collected in the San Francisco Bay district, Mt. Eden, Capitola, Hillsborough, Salinas, and Fresno. The expressed juice from delphiniums showing different calico patterns on the leaves was inoculated in healthy delphiniums, cucumber, and Turkish tobacco, and subinoculations were made from the last two plants back to healthy delphinium seedlings. Inoculations of healthy delphinium seedlings were also made with the virus extract from other naturally infected host plants of calico as follows : cantaloupe from Sacramento Pocket, celery from Milpitas, cucumber (plants and fruit) from San Pablo, Summer Crookneck squash (fruit) from Santa Cruz, and tomato from Berkeley. The results are shown in table 1. The inoculum from delphiniums and the various host plants of calico produced variable symptoms on the leaves of delphiniums regardless of the source of virus. 
TABLE 1

Incubation Period of Disease in Delphiniums Inoculated with Virus Extract from Host Plants Naturally INFected with Calico

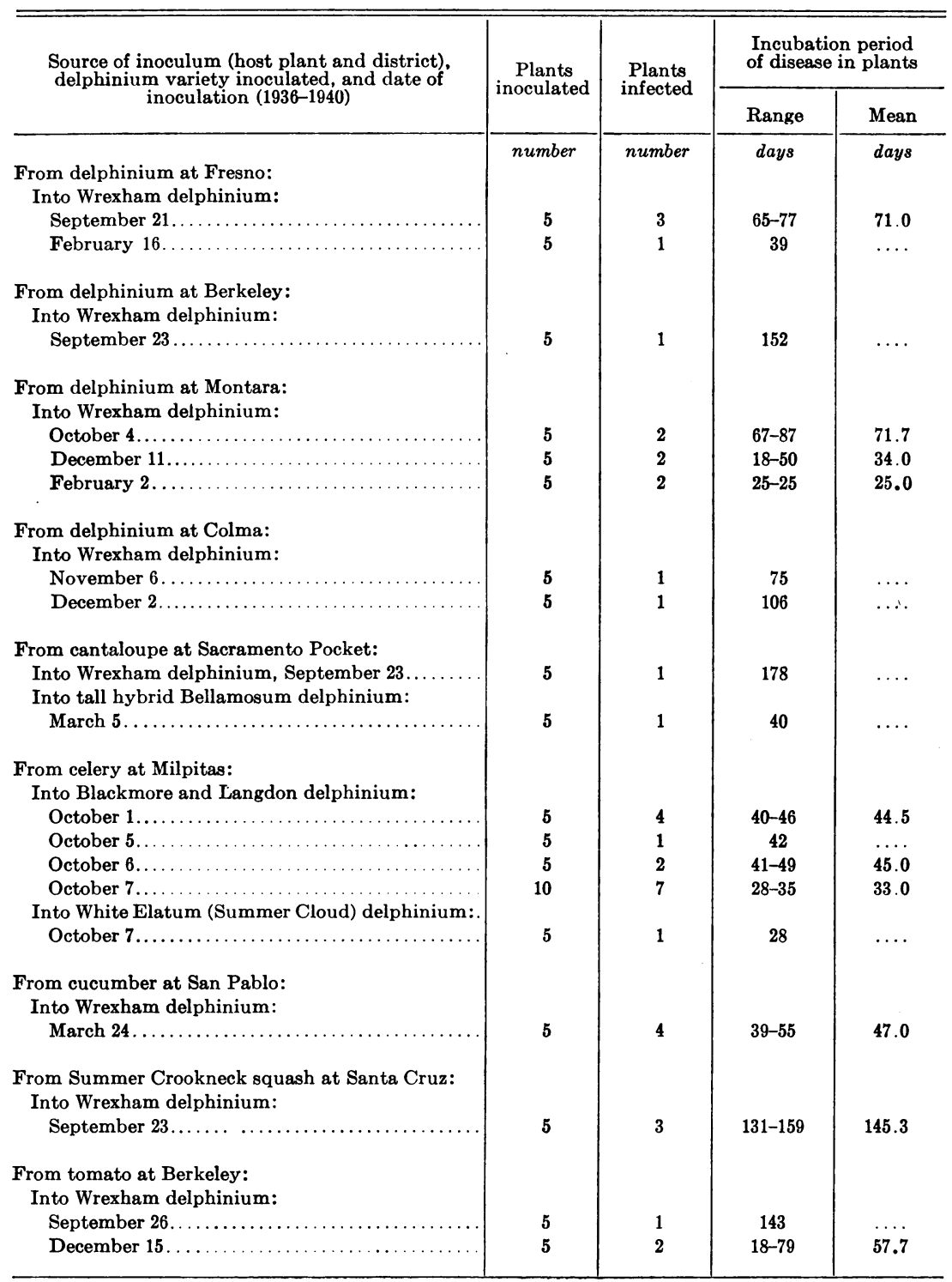


TABLE 2

List of Varieties and Hybrid Detphinium Seedlings Experimentally IN FeCted with Celery Calico, Incubation Period of Disease, and Recovery of Virus

\begin{tabular}{|c|c|c|c|c|c|c|}
\hline \multirow{2}{*}{$\begin{array}{c}\text { Delphinium variety or hybrid and date } \\
\text { inoculated }(1936-1940)\end{array}$} & \multirow{2}{*}{$\begin{array}{c}\text { Delphin- } \\
\text { iums } \\
\text { inocu- } \\
\text { lated }\end{array}$} & \multirow{2}{*}{$\begin{array}{l}\text { Delphin- } \\
\text { iums } \\
\text { infected }\end{array}$} & \multicolumn{2}{|c|}{$\begin{array}{l}\text { Incubation period } \\
\text { of disease in } \\
\text { delphiniums }\end{array}$} & \multicolumn{2}{|c|}{$\begin{array}{l}\text { Recovery of virus } \\
\text { from infected } \\
\text { delphiniums }\end{array}$} \\
\hline & & & Range & Mean & $\begin{array}{c}\text { Cucum- } \\
\text { bers } \\
\text { inocu- } \\
\text { lated }\end{array}$ & $\begin{array}{l}\text { Cucum- } \\
\text { bers } \\
\text { infected }\end{array}$ \\
\hline Blackmore and Langdon hybrids: & number & number & days & days & number & number \\
\hline June $28 \ldots \ldots \ldots \ldots \ldots \ldots \ldots$ & 2 & 2 & $19-19$ & 19.0 & 10 & 6 \\
\hline August $31 \ldots \ldots \ldots \ldots$ & 5 & 3 & $23-38$ & 30.0 & 15 & 15 \\
\hline \multicolumn{7}{|l|}{ Belladonna tall hybrids: } \\
\hline May $6 \ldots \ldots \ldots \ldots$ & 3 & 3 & $30-39$ & 34.0 & 15 & 9 \\
\hline June $12 \ldots \ldots \ldots \ldots$ & 3 & 3 & $17-24$ & 21.0 & 15 & 15 \\
\hline July $30 \ldots \ldots \ldots \ldots \ldots \ldots \ldots$ & 4 & 3 & $37-66$ & 56.3 & 15 & 15 \\
\hline $\begin{array}{l}\text { Chinensis grandiflorum var. album: } \\
\text { June } 12 \ldots \ldots \ldots \ldots \ldots \ldots \ldots \ldots \ldots\end{array}$ & 5 & 5 & $26-43$ & 34.0 & 25 & 25 \\
\hline \multicolumn{7}{|l|}{ Chinese Azure Blue: } \\
\hline June $24 \ldots \ldots \ldots \ldots \ldots \ldots \ldots$ & 3 & 2 & $20-33$ & 26.5 & 10 & 10 \\
\hline \multicolumn{7}{|l|}{ Chinese Dark Blue: } \\
\hline \multicolumn{7}{|l|}{ Clivenden Beauty: } \\
\hline \multicolumn{7}{|l|}{ Delphinium Parryi var. maritimum: } \\
\hline \multicolumn{7}{|l|}{ Delphinium Zalil: } \\
\hline $\begin{array}{l}\text { March } 12 \ldots \ldots \ldots \ldots \ldots \ldots \ldots \ldots \\
\text { Dreer's De Luxe Art shades: }\end{array}$ & \multicolumn{3}{|c|}{ Dreer's De Luxe Art shades: } & —* & 5 & 5 \\
\hline $\begin{array}{l}\text { June } 12 \ldots \ldots \ldots \ldots \ldots \ldots \ldots \\
\text { Dreer's De Luxe Dark-Blue shades: }\end{array}$ & 5 & Dreer's De Luxe Dark-Blue shades: & $15-28$ & 20.8 & 25 & 25 \\
\hline June $12 \ldots \ldots \ldots \ldots \ldots \ldots \ldots \ldots \ldots$ & 5 & 5 & $16-43$ & 25.0 & 25 & 25 \\
\hline September $17 \ldots \ldots \ldots \ldots \ldots \ldots$ & 1 & 1 & 52 & $\ldots$ & 5 & 5 \\
\hline October $15 \ldots \ldots \ldots \ldots \ldots \ldots \ldots$ & 3 & 3 & — $^{*}$ & $-^{*}$ & 15 & 15 \\
\hline \multicolumn{7}{|l|}{ Dreer's De Luxe Light-Blue shades: } \\
\hline June $28 \ldots \ldots \ldots \ldots \ldots \ldots \ldots$ & 3 & 2 & $23-26$ & 24.0 & 10 & 10 \\
\hline September $17 \ldots \ldots \ldots \ldots \ldots \ldots$ & 1 & 1 & 82 & $\ldots$ & 5 & 2 \\
\hline \multicolumn{7}{|l|}{ Dreer's De Luxe Mid-Blue shades: } \\
\hline August $31 \ldots \ldots \ldots \ldots \ldots \ldots$ & 5 & 1 & 35 & $\ldots$ & 5 & 0 \\
\hline June $12 \ldots \ldots \ldots \ldots \ldots \ldots$ & 5 & 5 & $16-17$ & 16.2 & 25 & 25 \\
\hline \multicolumn{5}{|l|}{ Dwarf Chinese Butterfly: } & 10 & 10 \\
\hline \multicolumn{7}{|l|}{ English hybrids Deep-Blue shades: } \\
\hline \multicolumn{6}{|l|}{ English hybrids Mid-Blue shades: } & 25 \\
\hline June $12 \ldots \ldots \ldots \ldots \ldots \ldots \ldots$ & 5 & 3 & $15-17$ & 15.7 & 15 & 15 \\
\hline October $15 \ldots \ldots \ldots \ldots \ldots \ldots$ & 5 & 1 & 41 & $\ldots$ & 5 & $\mathbf{5}$ \\
\hline \multicolumn{7}{|l|}{ English hybrids Pastel shades: } \\
\hline 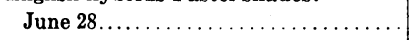 & 3 & 3 & $13-26$ & 21.0 & 15 & 15 \\
\hline \multicolumn{7}{|l|}{ Burpee's Floradale Giants Deep Blue: } \\
\hline June $29 \ldots \ldots \ldots \ldots \ldots \ldots \ldots \ldots$ & 1 & 1 & 一 $^{*}$ & $\ldots *$ & 5 & 5 \\
\hline August $31 \ldots \ldots \ldots \ldots \ldots \ldots \ldots$ & 5 & 3 & $23-26$ & 25.0 & 15 & 0 \\
\hline \multicolumn{7}{|l|}{ Burpee's Floradale Giants Light Blue: } \\
\hline June $28 \ldots \ldots \ldots \ldots \ldots \ldots \ldots \ldots$ & 2 & 2 & $14-14$ & 14.0 & 10 & 10 \\
\hline August $31 \ldots \ldots \ldots \ldots \ldots \ldots \ldots$ & 1 & 1 & 40 & & 5 & 5 \\
\hline September $17 \ldots \ldots \ldots \ldots \ldots \ldots \ldots$ & 2 & 2 & $23-45$ & 34.0 & 10 & 10 \\
\hline \multicolumn{7}{|l|}{ Burpee's Floradale Giants Mid Blue: } \\
\hline June $24 \ldots \ldots \ldots \ldots \ldots \ldots \ldots \ldots \ldots$ & 3 & 3 & $15-31$ & 21.0 & 15 & 0 \\
\hline August $31 \ldots \ldots \ldots \ldots \ldots \ldots \ldots \ldots$ & 5 & 3 & $23-40$ & 32.3 & 15 & 0 \\
\hline September $17 \ldots \ldots \ldots \ldots \ldots \ldots \ldots \ldots$ & 1 & 1 & 52 & $\ldots$ & 5 & 5 \\
\hline
\end{tabular}

* No symptoms, but virus recovered from infected delphiniums. 
TABLE 2-(Concluded)

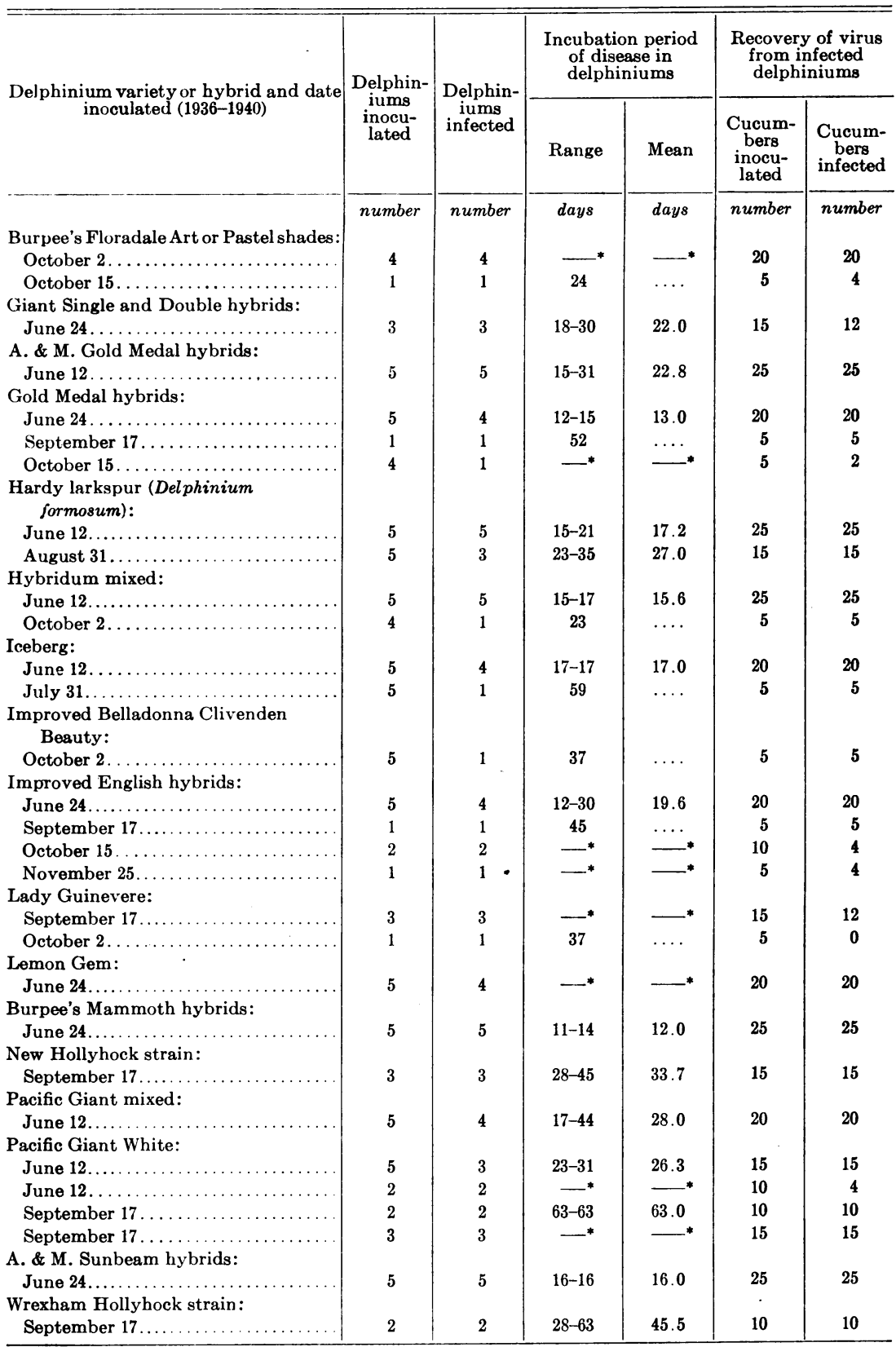

- No symptoms, but virus recovered from infected delphiniums. 
Varieties and Hybrids Inoculated.-The delphinium varieties and hybrids infected with the inoculum from various host plants naturally and experimentally with calico, are listed in tables 1 and 2 . All delphiniums listed in these tables were seedlings except the Wrexham, or Hollyhock, variety (table 1), which was used after the second year's growth.

Incubation Period of the Disease.-The period from the date of inoculation until the orange or yellow discoloration, line, or ring patterns appeared on the basal leaves of delphinium seedlings was considered as the incubation period of the disease.

As indicated in tables 1 and 2, the incubation period of the disease varied from 11 to 178 days.

During the past year, Pacific-strain second-year delphiniums infected with calico were marked in the field in Berkeley, and it was noted that in the new shoots appearing from the ground after the old stock was cut off, symptoms on the leaves were slower to develop in the summer than in the spring, and still slower in the fall. During the past mild winter (1941-42), the leaves on the new shoots failed to show symptoms even after the spikes developed.

Recovery of the Virus.-An attempt was made to recover the virus from some of the experimentally infected delphiniums during the second year. Fifteen delphinium seedlings were selected which showed prominent and characteristic symptoms of the disease and from which the virus had been recovered during the first year. All of the foliage was removed during November, and the roots were given a rest period during the winter. After a period of 9 to 12 months had elapsed since the seedlings had been inoculated, the juice was expressed from the new shoots and inoculated in Turkish tobacco and cucumber plants. The virus was not recovered from 1 delphinium plant which showed typical symptoms of the disease during the first and second years. But it was recovered from the other 14 experimentally infected plants, 4 of which failed to show symptoms of the disease during the second year. Evidently some infected delphinium plants are symptomless carriers of the disease during the second year.

Delphinium plants which appeared to be infected with a cucumber mosaic were found under natural conditions; others revealed a mottling of the leaves resembling a mosaic disease, and many showed dried, brown flowers with or without malformed leaves. Repeated cross inoculations were made from these abnormal plants (transplanted in a glasshouse) to healthy delphinium seedlings, but all attempts to reproduce the symptoms were failures. Frequently these abnormal plants also showed symptoms of aster yellows or sometimes calico. The virus of 
calico was sometimes recovered from these abnormal plants, which failed to show symptoms of calico on the leaves. Evidently some of these abnormal plants were symptomless carriers of calico and served as reservoirs of the virus. It is not to be inferred, however, that the calico virus produced the abnormalities.

\section{HOST RANGE}

In this paper the symptoms of calico on a few cultivated plants are described, and compared with the symptoms described by Burnett (1). According to Burnett (1) the host of range of delphinium "stunt" (aster yellows) includes 12 species of plants: Connecticut Havana tobacco, tomato, cucumber, petunia, zinnia, and 7 species of weeds. The source of virus was from naturally infected delphiniums transplanted in boxes in the greenhouse.

Tobacco.-The earliest symptom of calico on Turkish tobacco, Nicotiana Tabacum, infected with the virus extract from diseased celery or delphinium plants is broken, concentric, necrotic, circles (plate $3, A$ ) which appear in 4 days or longer on the inoculated leaves. The circles are composed of necrotic dots (plate $3, B$ ) when examined under a binocular microscope. The next symptom on the inoculated leaves is the oak-leaf pattern (plate $3, C$ ) consisting of necrotic dots and lines. A striking oakleaf pattern also developed on the leaves of $N$. Langsdorfi (plate $3, D$ ). In the advanced stage of the disease, the entire inoculated leaf may show variable ring and oak-leaf patterns (plate $3, E, F$ ). The necrotic ring and oak-leaf patterns are confined usually to the inoculated leaves and sometimes to a few subsequently developing leaves. As infected Turkish tobacco plants grow older, the inoculated leaves and those above the inoculated ones exhibit intervenal, circular, chlorotic areas (plate 4, $A$ ), which coalesce and form irregular, blotchy mottle (plate $4, B$ ) that extend to near the midrib (plate 4, $C, D$ ). The leaves below the flowers may show faint, chlorotic areas (plate $4, E, F, G$ ) or no symptoms.

Burnett (1) described and figured a white, necrotic, etching, with ring-and-line pattern of variable forms confined to the first few leaves on Connecticut Havana tobacco, Nicotiana Tabacum, as a result of inoculation from delphiniums affected with "stunt." He also described and figured a blotchy, irregular, usually intervenal mottle which may coalesce to form extensive chlorotic areas involving the major part of the older leaves. These symptoms correspond to those produced by the virus of calico on Turkish tobacco. This indicates that Burnett probably was transmitting the calico virus from the delphiniums affected by a combination of the aster-yellows and calico viruses, since some of the symptoms on delphiniums were those of aster yellows (see p. 412). 
Valleau (7) described and figured a ring-and-line pattern resembling calico on the leaves of Turkish tobacco rubbed with the extract from a virus disease of delphinium in Kentucky.

White Spine Cucumber.-The first symptom that often develops on the cotyledons of infected seedlings of White Spine cucumber, Cucumis sativus, 2 days or longer after inoculation, is large, pale-green circular areas which later are surrounded by chlorotic rings (plate 5, $A$ ). The next symptom which appears on the younger leaves is numerous, small, circular, chlorotic spots (plate $5, B$ ), which coalesce and form irregular, yellow areas (plate $5, C$ ) that spread over the leaves. The petiole is bent and the youngest leaves are sometimes cupped inward. In a late stage of the disease, the older leaves become chlorotic except for bands of green tissue extending along some of the veins (plate $5, D$ ). Cucumber fruits show irregular, chlorotic mottling (plate $5, E, F$ ).

The symptoms on cucumber described by Burnett (1) as resulting from inoculation from delphinium are not those produced by the virus of calico. He reports that the fruit which matured failed to show evident symptoms.

Marglobe Tomato.-The symptoms of calico on Marglobe tomato plants, Lycopersicon esculentum, begin on the lower or older leaves of tomato plants, and appear as an orange discoloration on a portion of the leaflets (plate 6, $A$ ) and spread until the entire leaf is affected. A progressive orange discoloration of the lower leaves on the main stem and lateral branches continues, but the younger leaves remain green. This symptom of calico may be readily overlooked, since a natural yellowing of the lower leaves occurs on healthy check or control plants, especially on old plants. Sometimes green islands occur in the orange discoloration.

The symptoms on tomato described by Burnett (1) do not correspond to those produced by the virus of calico. He states, however, that fern leaf is not caused by the delphinium virus alone.

Rosy Morn Petunia.-The first symptom of the disease which appeared on Rosy Morn petunia, Petunia hybrida, was a clearing of the veins (plate $6, C$ ) 6 days or longer after inoculation with the virus extract from delphinium infected with celery calico. In the later stage of the disease, the basal or lower leaves become orange in color; sometimes the tissue along the midrib remains green. The older ascending leaves develop variable orange and green patterns (plate $6, F, G, H$ ), sometimes deep-green blotches in the chlorotic tissue, or an oak-leaf pattern along the midrib and lateral veins (plate $6, D, E$ ).

Symptoms were not evident on Petunia hybrida, according to Burnett, (1) but the virus was recovered when subinoculations were made to tobacco plants. 


\section{MULTIPLE VIRUSES}

It seems likely that Burnett (1) was dealing with multiple viruses in his host-range studies. He unquestionably failed to reproduce the symptoms of aster yellows on delphinium by juice inoculation since this virus is inactivated in expressed juice (4). Possibly the inoculum from naturally infected delphiniums may have contained the calico virus. His inoculations into Connecticut Havana tobacco indicate this to be the case but his inoculations into other host plants do not substantiate this interpretation.

A delphinium plant sometimes contains both calico and aster-yellows viruses in the field, and the inoculum from such a plant produces infection of calico but not aster yellows. The aster-yellows virus was recovered from the virus complex in delphinium plants by previously noninfective mountain leafhoppers, Thamnotettix montanus Van D., geminate leafhoppers, T. geminatus Van D., and the long-winged aster leafhoppers, Macrosteles divisus (Uhl.).

Tomato plants are frequently infected with a mixture of viruses under natural conditions ; for example, ordinary tobacco mosaic identical with tomato mosaic (tobacco virus 1) and calico. The virus of ordinary tobacco mosaic sometimes produces symptoms described as fern leaf, filiform leaf, or shoestring leaf (plate $6, I$ ), when young, slow-8 : wing tomato plants are inoculated and kept under low temperatures and light intensity, but the calico separated from the virus complex rarely induces such symptoms. When the multiple viruses in the tomato extract are inoculated in cucumber plants, tobacco mosaic is filtered out and the calico virus is retained.

\section{GEOGRAPHIC RANGE OF THE VIRUS}

California.-Perennial delphiniums naturally infected with the celery-calico virus were collected in the San Francisco Bay districts, in the Santa Clara, Salinas, and San Joaquin valleys, and in Capitola, Montara, and Hillsborough. Celery calico has been found in all of the large celery districts of California.

Washington.-G. A. Huber, Western Washington Experiment Station, Puyallup, Washington, kindly sent 2 celery plants showing typical symptoms of calico. The virus extract from these 2 plants was mechanically inoculated into five known hosts of celery calico, 5 plants being used in each test. The numbers of these that became infected were : Wrexham delphinium 5, celery 2, White Spine cucumber 5, Turkish tobacco 3, and Nicotiana glutinosa 3 . It is evident that the virus of celery calico from Washington is identical with that from California. 
Idaho.-One of two delphinium witches' broom (aster yellows) (4) sent from Mullan, Idaho, by C. D. Miller, showed typical symptoms of calico while the other plant was a symptomless carrier of the virus. The virus extract from these two plants inoculated into 5 known hosts of celery calico produced the following infections : 5 Blackmore and Langdon delphiniums, 18 celery, 29 White Spine cucumbers, 5 Turkish tobacco, and 5 Nicotiana glutinosa. The results indicate that the virus separated from this virus complex is probably identical with the virus of celery calico from California and the range of the virus may thus be tentatively extended to Idaho.

\section{APHID VECTORS}

The natural occurrence of colonies of aphids on delphinium plants has never been observed in California by the author. Occasional winged aphids were found on delphiniums under natural conditions, but most of these were dead.

It was difficult to infect delphinium seedlings with calico by means of any of the species of aphids tested, even though each plant was inoculated with the virus by two lots of 40 aphids each. The following species of aphids reared on celery infected with calico, did, however, transmit the virus to healthy delphinium seedlings to which they were transferred:

Celery leaf aphid, Aphis apigraveolens Essig

Celery aphid, Aphis apii Theobald

Rusty-banded aphid, Aphis ferruginea-striata Essig

Cotton, or melon, aphid, Aphis gossypii Glover

Erigeron root aphid, Aphis middletonii Thomas

Lily aphid, Myzus circumflexus (Buck.)

Foxglove aphid, Myzus convolvuli (Kalt.)

Green peach aphid, Myzus persicae (Sulz.)

Honeysuckle aphid, Rhopalosiphum melliferum (Hottes)

The virus was recovered by previously noninfective cotton, or melon, aphids, Aphis gossypii, from a delphinium plant infected by this species of aphid and transferred to a healthy celery plant. No difficulty was experienced in recovering the virus from delphiniums infected with the nine listed species of aphids by mechanical inoculation of the virus extract into healthy delphinium, celery, and cucumber plants.

Winged green peach aphids occasionally were taken on delphiniums grown in the field, and an attempt was made to recover the virus by previously noninfective aphids from naturally infected delphiniums and transfer it to healthy plants. The virus was transmitted to 2 of the 17 plants that were inoculated. A high mortality of the aphids occurred on delphiniums. 


\section{SUMMARY}

A virus disease of perennial delphinium has been proved to be celery calico.

The symptoms of celery calico on delphiniums are confined to the basal and intermediate leaves and are variable, including pale-yellow, amber, or lemon-yellow areas, or line or ring patterns. The virus does not cause abnormal flowers or breaking in the color of the flowers.

The incubation period of the disease ranged from 11 to 178 days.

Delphiniums either naturally or experimentally infected during the first year may be symptomless carriers of the virus during the second year.

Calico is often associated with aster yellows in delphiniums under natural conditions, and the inoculum from such plants produces infection of calico but not aster yellows. The aster-yellows virus was recovered from the virus complex by three species of leafhoppers.

Tomato plants are sometimes infected with a mixture of viruses. $\mathrm{Cu}$ cumber plants, when inoculated with the virus extract, filter out ordinary tobacco mosaic virus and retain the calico virus.

Nine species of aphids were demonstrated to be vectors of the virus.

\section{ACKNOWLEDGMENTS}

Assistance of nontechnical employees was furnished by the personnel of the Works Progress Administration Official Project No. 65-1-08-91. 


\section{LITERATURE CITED}

1. BURNETT, G.

1934. Stunt, a virosis of delphinium. Phytopathology $24: 467-81$.

2. Hrats, F. D., and G. BURNeTT.

1934. A virus disease of perennial delphiniums. Washington Agr. Exp. Sta. Sci. Paper No. 275:1-8. (Reprinted from Amer. Delphinium Soc. Bul. 2[2]: 14-21. 1934.)

3. RAWLINS, T. E., and C. M. ToMpkINs.

1936. Studies on the effects of carborundum as an abrasive in plant virus inoculations. Phytopathology 27:578-87.

4. SEVkRiN, H. H. P.

1942. Infection of perennial delphiniums by California-aster-yellows virus. Hilgardia 14(8) :411-40.

5. Severin, H. H. P., and J. H. Freitag.

1935. California celery-mosaic diseases. Phytopathology 25:891.

6. Severin, H. H. P., and J. H. Freitag.

1938. Western celery mosaic. Hilgardia 11(9):493-558.

7. VaLlegad, W. D.

1932. A virus disease of delphinium and tobacco. Kentucky Agr. Exp. Sta. Bul. 327:81-88. 

PLATES 



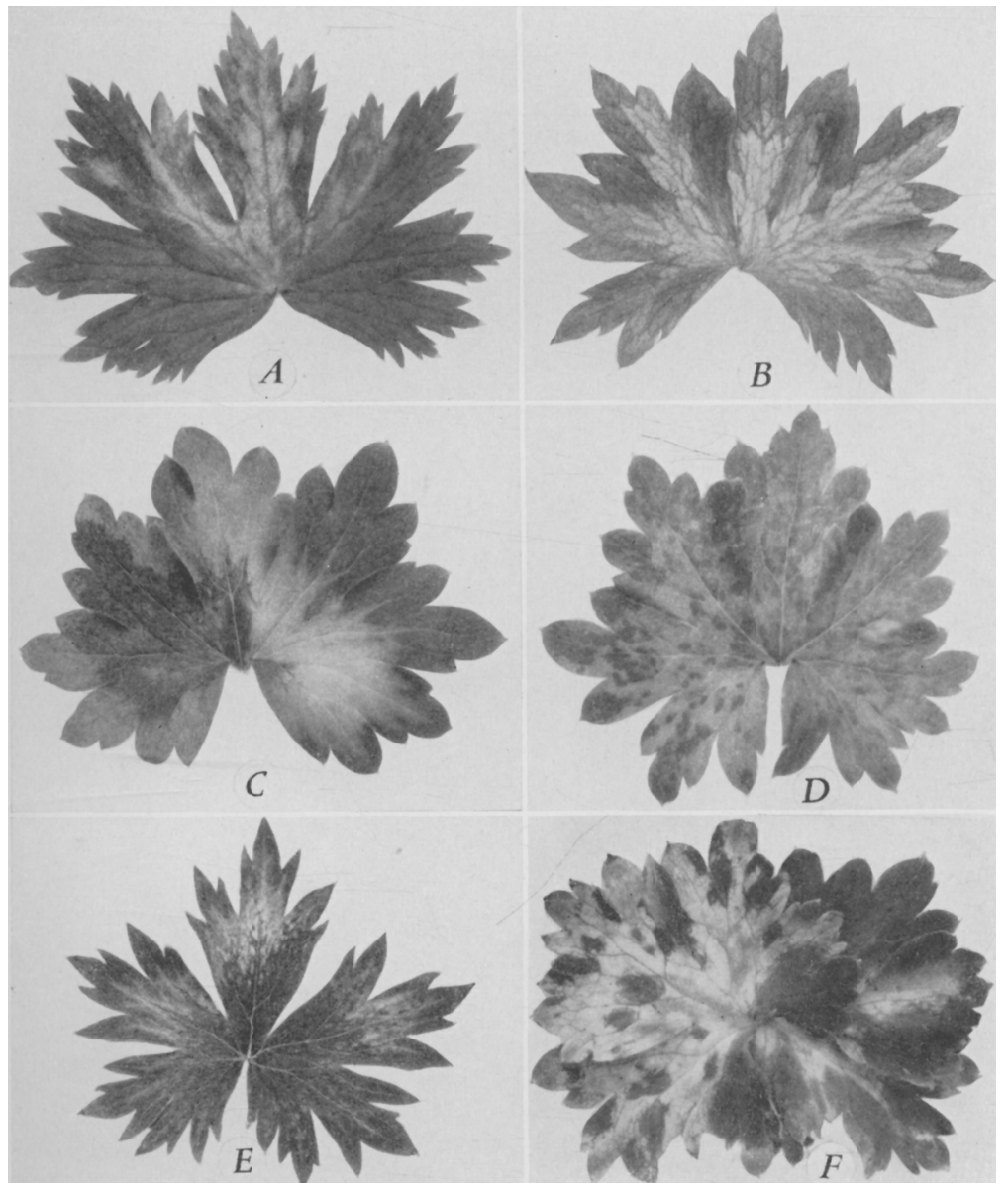

Plate 1.-Delphinium leaves showing symptoms of celery calico from plants grown from seeds and infected with the virus by mechanical inoculation: $A$, leaf showing irregular, yellow discolorations on three lobes or divisions from a seedling infected with the virus extract from Summer Crookneck squash (fruit) naturally infected with calico; $B$, leaf from a delphinium seedling inoculated with the juice extracted from the same squash, showing yellow areas extending into all lobes; $C, D$, two leaves showing variation in symptoms from the same delphinium seedling inoculated with the juice from celery calico, $C$ showing leaf discoloration and $D$ green areas in the chlorotic regions; $E$, leaf showing yellow speckling and streaks from a seedling inoculated with the virus extract from a tomato plant naturally infected with calico; $\boldsymbol{F}$, leaf showing green islands in the lemon-yellow areas from a seedling inoculated with the expressed juice from a delphinium plant naturally infected with the disease. 


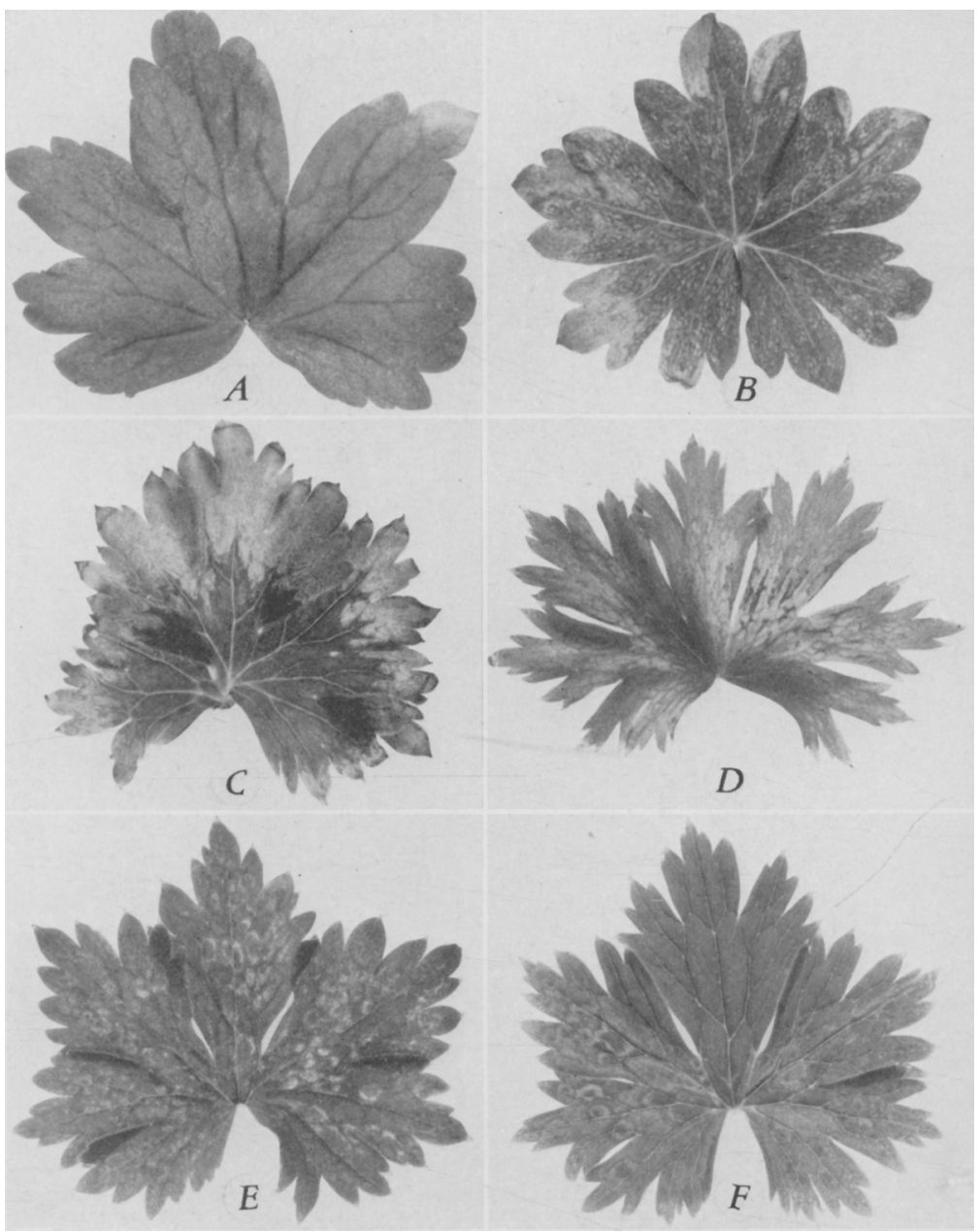

Plate 2.-Delphinium leaves showing symptoms of celery calico from plants grown from seeds and experimentally infected by mechanical inoculation: $A, B$, leaves from delphinium seedlings inoculated with the virus extract from celery calico, showing broken-line patterns composed of a series of dots or dashes; $C$, margin of leaf showing alternating green and yellow lines from a seedling inoculated with the juice extracted from a delphinium plant naturally infected with calico; $D$, leaf showing green streaks in the chlorotic areas from a seedling inoculated with the extract from Summer Crookneck squash (fruit) naturally infected with calico; $E, F$, leaves from delphinium seedlings inoculated with the expressed juice from celery calico showing ring patterns composed of chlorotic dots encircling green areas or concentric, alternating yellow and green lines surrounding green centers. 


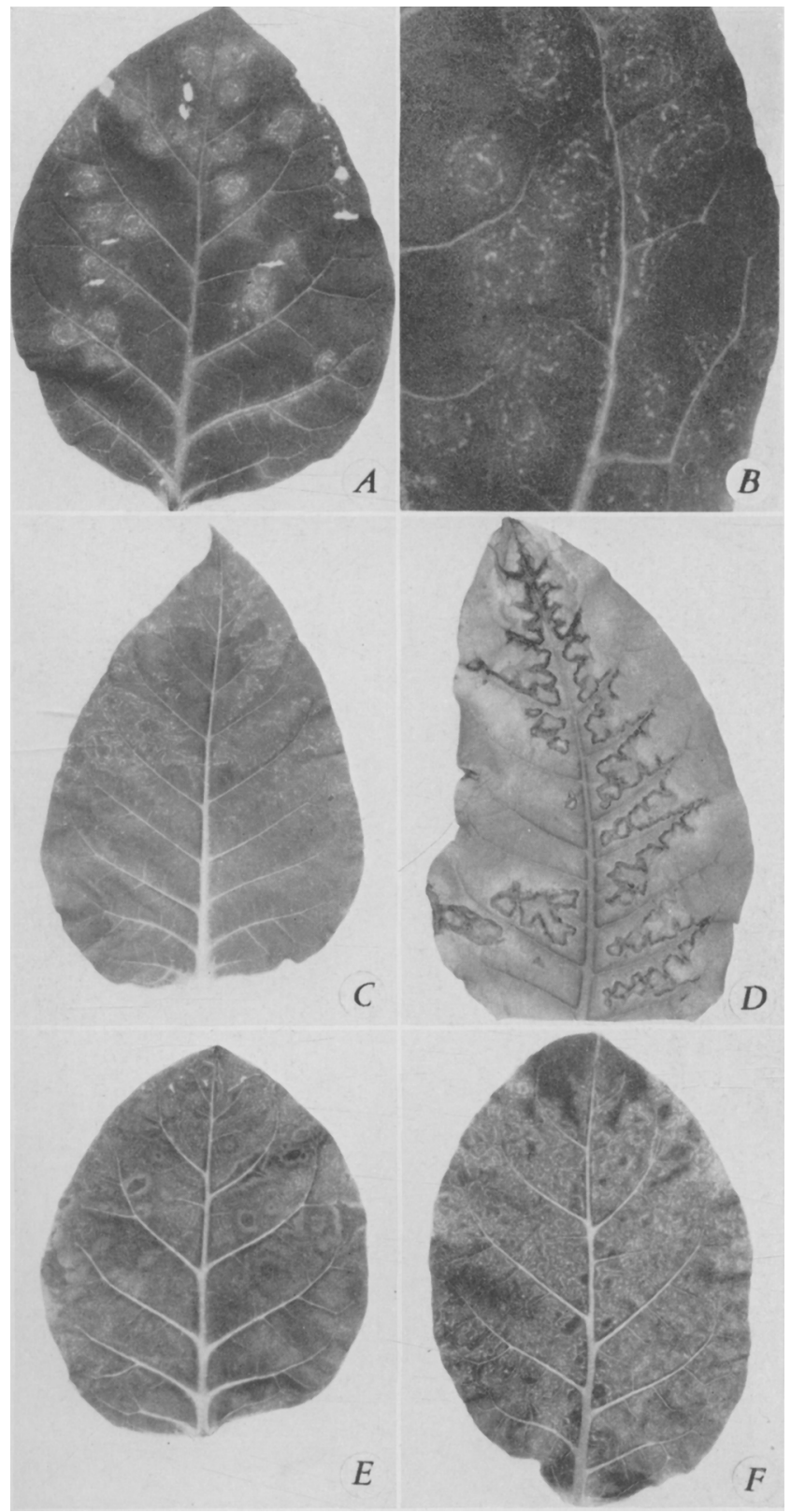

Plate 3.-Leaves from Turkish tobacco (Nicotiana Tabacum) and $N$. Langsdorfii infected with the celery-calico-virus extract from celery or from delphinium by mechanical inoculation: $A$, concentric, necrotic, broken circles-white areas are abrasions caused by inoculation with carborundum; $B$, portion of Turkish tobacco leaf enlarged showing necrotic dots arranged to form concentric, broken, ring patterns; $C$, etch or oak-leaf pattern consisting of necrotic dots and lines; $D$, leaf from $N$. Langsdorfi showing oak-leaf pattern; $E$, leaf from Turkish tobacco in an advanced stage of the disease showing chlorotic rings encircling green areas and line patterns; $\boldsymbol{F}$, intervenal, necrotic, etch pattern. 


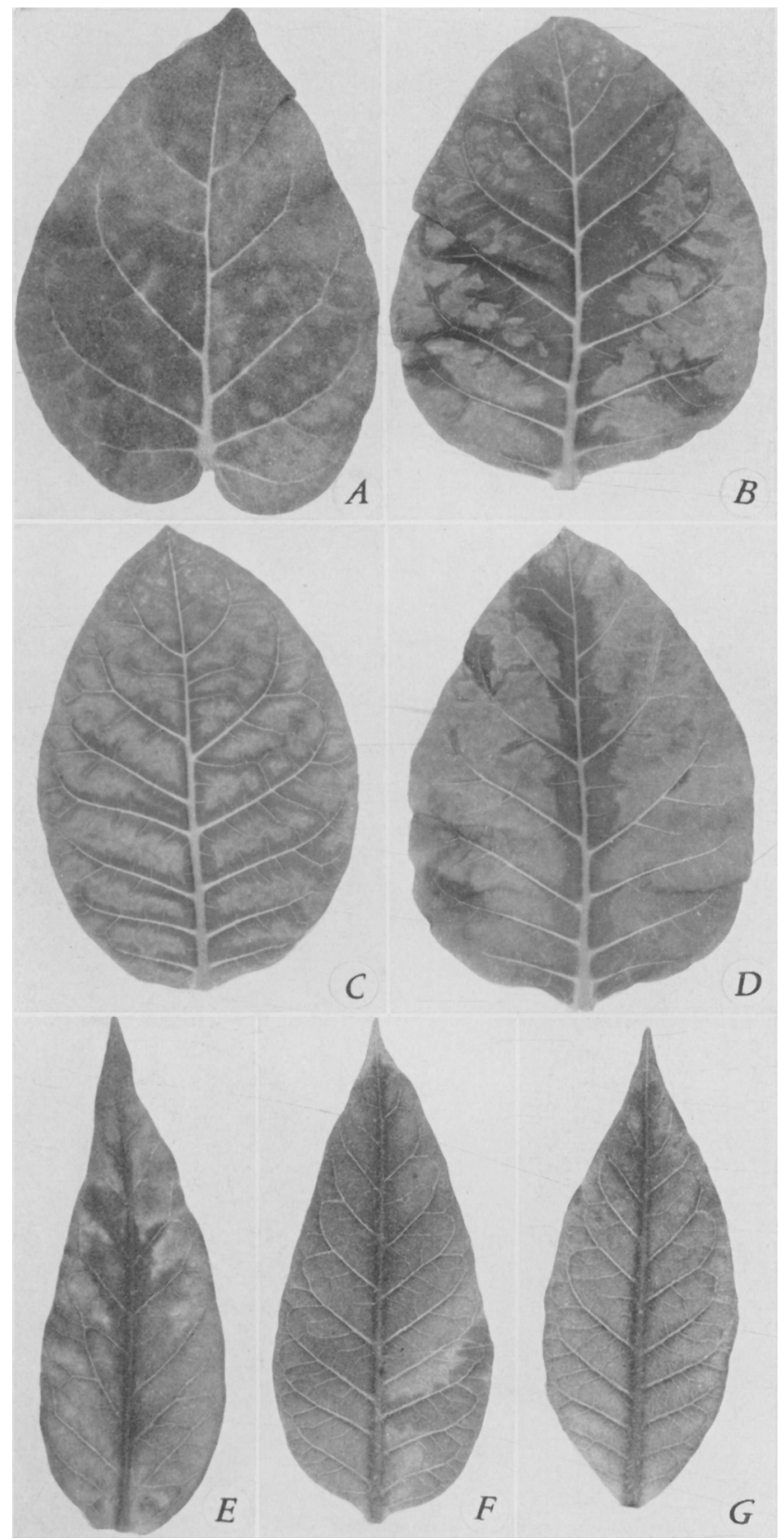

Plate 4.- - Leaves from Turkish tobacco (Nicotiana Tabacum) infected with the virus of celery calico from delphinium by mechanical inoculation: $A$, intervenal, chlorotic, circular areas which coalesce and form irregular, blotchy mottle, as at $B$, that often extend to the midrib, as at $C, D ; E, F$, leaves below flowers showing faint chlorotic areas; $G$, chlorosis extending over almost the entire leaf. 


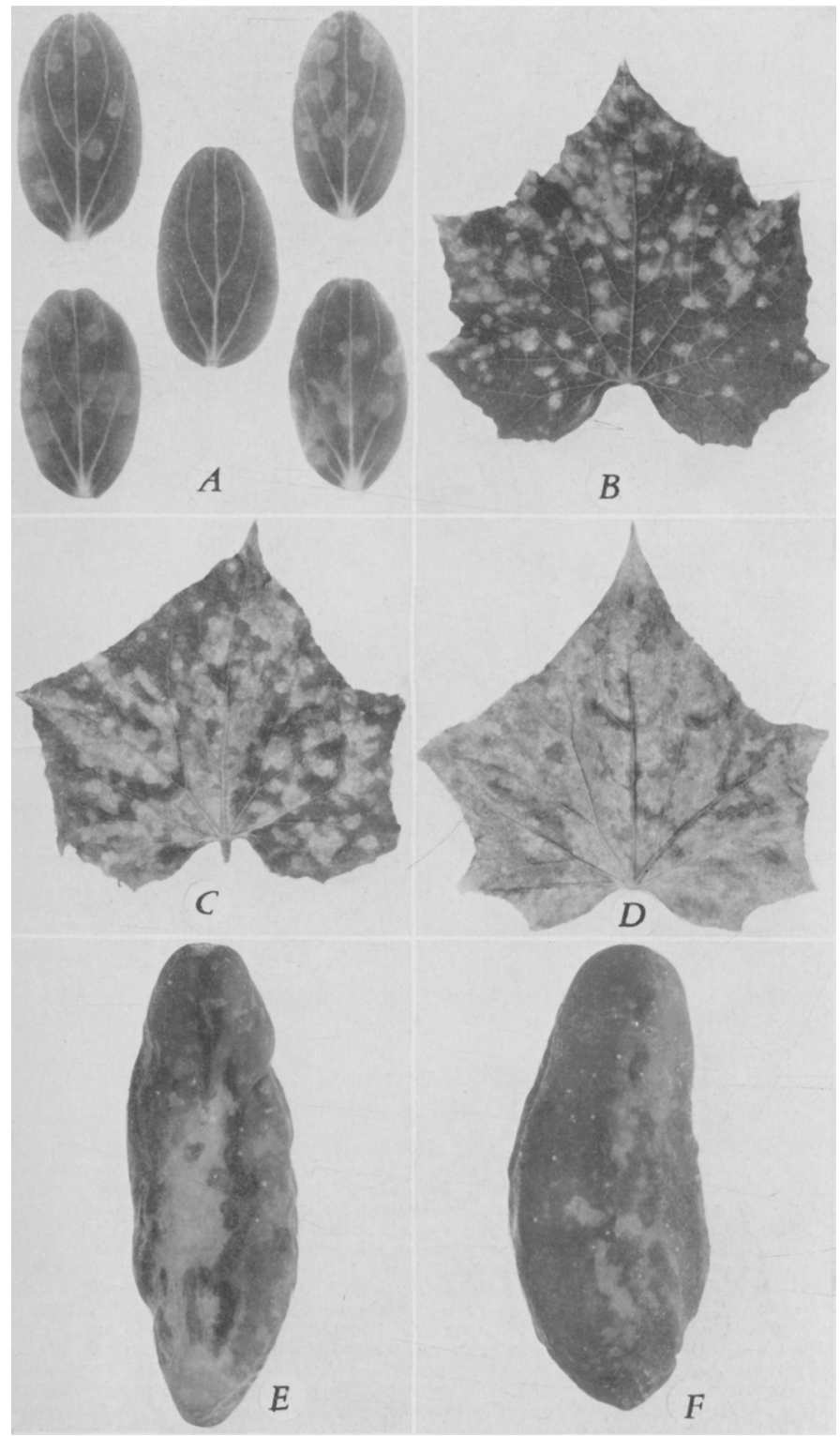

Plate 5.-White Spine cucumber (Cucumis sativus) infected with the virus of celery calico from delphinium by mechanical inoculation: $A$, center, cotyledon from check or control plant and grouped around it four cotyledons showing chlorotic rings enclosing large green areas; $B$, leaf showing numerous, small, circular, chlorotic spots, which coalesce to form irregular, yellow areas, as at $C$, that spread over the leaf; $D$, leaf showing advanced stages of chlorosis with green bands of tissue extending along some of the veins; $\boldsymbol{E}, \boldsymbol{F}$, cucumber fruits showing irregular, chlorotic mottling. 


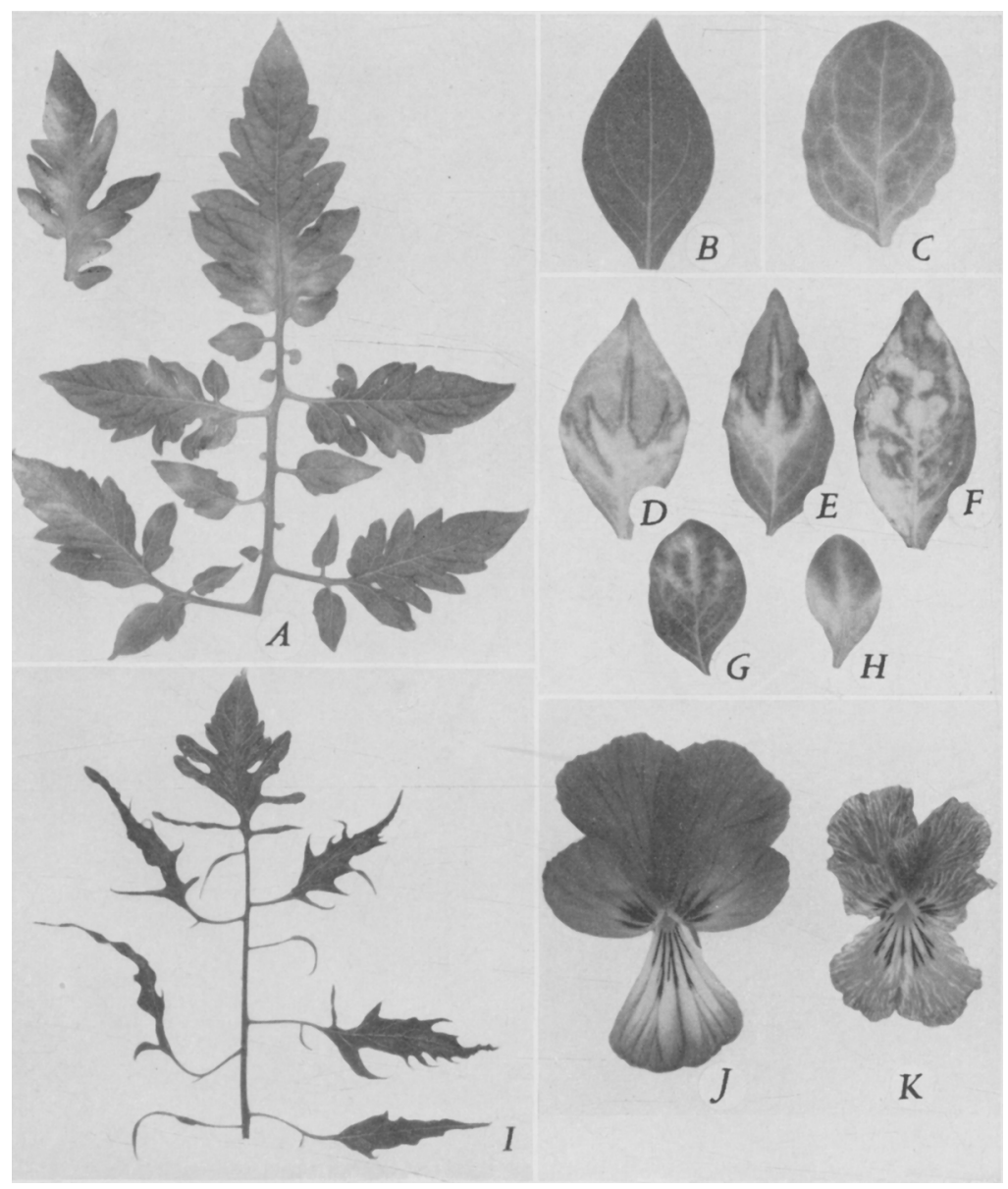

Plate 6.-A, Marglobe tomato (Lycopersicon esculentum) experimentally infected with celery calico, leaf and leaflet showing light areas on leaflets which were orange in color. $B-H$, Rosy Morn petunia (Petunia hybrida) infected with the virus of celery calico from delphinium : $B$, healthy leaf from check or control plant; $C$, leaf showing cleared venation 6 days after inoculation: $D, E$, oak-leaf pattern extending along the midrib and lateral veins; $F$, variable orange and green patterns on a lower or basal leaf; $G$, orange discoloration along the veins near the tip of a basal leaf; $H$, orange discoloration near the basal region of a lower leaf and extending along the midrib. I, Fern leaf, filiform leaf, or shoestring leaf on Marglobe tomato, sometimes produced by tomato mosaic (identical with ordinary tobacco-mosaic virus, tobacco mosaic 1 ); but the celery-calico virus separated from tobacco mosaic in a virus complex in naturally infected tomato plants rarely induces such symptoms. $J-K$, Papilio viola (Viola cornuta) $: J$, flower from a healthy plant used as a check or control plant; $K$, breaking in color of flower from a plant inoculated with the virus extract from delphinium naturally infected with celery calico. 